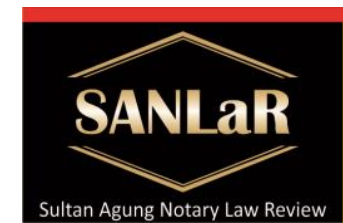

Volume 3 No. 1, March 2021

\section{Sultan Aqung Notary Law Review}

ISSN 2686-4428

published by

Master of Notarial Law

Universitas Islam Sultan Agung Semarang

Implementation of Notary Public...(Zahren Zukri Alyafie)

\title{
Implementation of Notary Public Liability against Authentic Deed Made According to Act No. 2 of 2014 Concerning Amendments to Act No. 30 of 2004 Regarding Notary Position
}

\author{
Zahren Zukri Alyafie ${ }^{*}$ and Amin Purnawan ${ }^{* *}$
}

*) Student of Master of Notary Law, Faculty of Law, Universitas Islam Sultan Agung (UNISSULA) Semarang, E-mail: zukrizahren@gmail.com

$\left.{ }^{* *}\right)$ Lecturer of Master of Notary Law, Faculty of Law, Universitas Islam Sultan Agung (UNISSULA) Semarang

\begin{abstract}
This study aims 1) To find out the implementation of the Notary Public Responsibilities on the Authentic Deed made according to Act No. 2 of 2014 concerning Amendments to Act No. 30 of 2004 concerning Notary Position in Kendari City; 2) To find out obstacles and solutions in the Implementation of Notary Responsibilities for the Authentic Deed he made in Kendari City. This study uses an empirical juridical approach, the specification of this research is descriptive analytical. Types of data in this study include primary data and secondary data. Data obtainedwith the method of interview and literature study. The data analysis technique is qualitative. Based on this research it is concluded that: 1)Implementation of Civil Notary Responsibilities for the Authentic Deed that he makes, the notary is only responsible for the formal correctness of an authentic deed and not for the material of the authentic deed. The legal basis used in civil liability for deeds made by the Notary is if the Notary makes a mistake due to broken promises as determined in the provisions of Article 1234 of the Civil Code and acts against the law as stipulated in the provisions of Article 1365 of the Civil Code.2) Barriers and Solutions in the Implementation of Notary Responsibilities for the Authentic Deed that he makes, namely: a) Obstacles in Implementing the Notary's Responsibility towards the Authentic Deed that he makes, if one of the parties then feels that someone has been harmed, in this case it is the responsibility of the parties, not the responsibility of the notary. In fact, deeds made by notaries are evidence that the parties can use. b) Solutions in the Implementation of Notary Responsibilities for the Authentic Deed He Made If it is proven that there is a violation committed by the notary concerned and it is detrimental to one of the parties because of the deed he made. Regarding the civil claim, the notary concerned is obliged to compensate for the civil loss if proven.
\end{abstract}

Keywords: Legal Responsibility; Notary Public; Authentic Deed. 


\section{Introduction}

Notary Public is a professional term for someone who has received legal education who is licensed by the government to do legal things, especially as a witness signing on documents. ${ }^{1}$

The definition of a notary in the Civil Law system as regulated in Article 1 Ord, stbl. 1860 Number 3 concerning the Position of Notary in Indonesia came into effect on July 1,1860 which was later translated by Soegondo Notodisoedo (1993) which states that the meaning of a Notary is as follows: ${ }^{2}$

Notary is a public official, in particular (the only one) who is authorized to make authentic deeds regarding all actions, agreements, and decisions which are required by general legislation to be desired by those concerned, that it is stated in an authentic letter., guaranteeing the date, keeping the deeds and issuing grosse, copies (derivatives) and quotations thereof, all when the making of such deeds or is devoted to officials or other people.

Notary in carrying out a task, whether it is a job assignment or a professional task, each implementation requires the responsibility of each individual who carries it out. Because the responsibility itself arises because of the responsibility of getting a trust to carry out a task or to gain a trust or because of getting a mandate to occupy a position or position.

Notary as one of the law enforcers because the Notary makes written evidence which has the power of proof. Legal experts are of the opinion that the notary's deed can be accepted in court as absolute evidence regarding its content, but even so there can be denial with evidence to the contrary by witnesses, which can be proven that what is explained by the notary in his act is true. ${ }^{3}$

However, the Notary is not responsible for the negligence and errors of the contents of deeds made before him, but the Notary is only responsible for the formal form of an authentic deed as indicated in Article 65 of Act No. 2 of 2014 concerning amendments to Act No. 30 of 2004 concerning Position Notary stating that: ${ }^{4}$

"Notaries, Substitute Notaries, and Temporary Officers of Notaries are responsible for any Deeds they make even though the Notary Protocol has been submitted or transferred to the depositary of the Notary Protocol."

Regarding the responsibilities of a notary as a public official relating to material truth, it is divided into four points, namely:

1. The notary's responsibility for the correctness of the material regarding the deed he makes;

2. Civil notary responsibility for the correctness of the material in the deed he makes;

3. The responsibility of the Notary based on the Notary Position Regulation regarding the correctness of the material in the deed he makes;

\footnotetext{
https://id.wikipedia.org/wiki/Notaris (Accessed on October 2, 2019 at 01.08 WITA).

Ngadino, (2019). Tugas Dan Tanggung Jawab Jabatan Notaris di Indonesia. Semarang: UPT Penerbitan Universitas PGRI Semarang Press. p. 3.

3 Tedjosaputro, Liliana. (1991). Malpraktek Notaris Dan Hukum Pidana. Semarang: Agung. p. 4.

$4 \quad$ Ngadino, (2019). Op.Cit. p. 11-12.
} 
4. The responsibility of the Notary in carrying out his/her duties based on the Notary Code of Ethics. ${ }^{5}$

The responsibility of a notary as a general official includes the responsibility of the notary profession itself related to deeds. In connection with the said authority, the Notary can be held responsible for his actions/work in making authentic deeds. The responsibilities of a notary as a general official include the responsibility of the Notary profession itself related to deeds, including:

1. Civil notary responsibility for the deed he makes. The responsibility in this case is the responsibility for the material correctness of the deed, in the construction of illegal acts. Actions against the law here are active or passive. Active, in the sense of committing an act that causes harm to other parties. Meanwhile, passive means that you do not commit an act which is a must, so that the other party suffers a loss. So the elements of an act against the law here are the existence of an act against the law, an error and the loss caused.

2. The notary's responsibility is criminally responsible for the deeds he has drawn up. Criminal in this case is a criminal act committed by a notary in his capacity as a public official who is authorized to make deeds, not in the context of an individual as a citizen in general.

3. The notary's administrative responsibility for the deeds he makes. Administrative sanctions based on Act No. 2 of 2014 states that there are 5 (five) types of administrative sanctions given if a Notary violates the provisions of Act No. 2 of 2014, namely:

a. Verbal warning;

b. Written warning;

c. Temporary suspension;

d. Honorific dismissal; and

e. Disrespectful dismissal.

In other words, the deed made by a notary has an authentic character, not because the law stipulates it, but because the deed is made by or before a public official, as referred to in Article 1868 of the Civil Code.

Based on the above background, this research problem is formulated as follows: First how is the implementation of the Notary Public Responsibility on the Authentic Deed made according to Act No. 2 of 2014 concerning Amendments to Act No. 30 of 2004 concerning the Position of Notary Public in Kendari City, Second, what are the obstacles and solutions in the Implementation of Notary Public Responsibilities for The authentic deed he made in Kendari City.

\section{Research Methods}

Method is a basic process regarding procedures for finding a solution to a problem, while research is a careful examination of signs in order to obtain human knowledge, then the research method can be interpreted as the basis of procedures for finding

\footnotetext{
${ }^{5}$ Anshori, Abdul Ghofur. (2009). Lembaga Kenotariatan Indonesia. Yogyakarta: UII Press. p. 16.
} 
solutions to problems that exist in carrying out research. ${ }^{6}$ This research approach is a juridical empirical approach.

The specification of this research is descriptive analytical. Types of data in this study include primary data and secondary data where secondary data is obtained from primary legal materials, secondary legal materials and tertiary legal materials.

Primary data In this research, it was obtained through the method of interviewing the parties concerned (informants) Kendari City Notaries. Secondary data, obtained from official documents, books related to the object of research, research results in the form of reports, theses, theses, dissertations, and laws and regulations. ${ }^{7}$ The data analysis technique used in data processing and data analysis used in this study is qualitative.

\section{Results and Discussion}

3.1 Implementation of Civil Notary Responsibilities for Authentic Deeds Made According to Act No. 2 of 2014 concerning Amendments to Act No. 30 of 2004 concerning the Position of Notary Public in Kendari City

Every community in carrying out civil law relations whether it is buying and selling, leasing and/or other legal relationships, of course, preceded by an agreement between the two parties. According to Subekti, an agreement is an event where someone promises to another person, or where the two people promise each other, or where two people promise each other to do something. ${ }^{8}$

In article 1 point 7 UUJN states that notary deed is an authentic deed made by or before a notary according to the form and procedure stipulated in this law. This article is an affirmation of article 1868 of the Civil Code which states "an authentic deed is a deed made in the form determined by law by or before a public official who has the authority to do so at the place where the deed was made". so it is clear that the deed made by the notary is an authentic deed.

Based on the sound of the article, it can be seen that the elements in a deed listed in article 1868 of the Civil Code are deeds made in a form that has been regulated according to legislation, the notarial deed is drawn up by or in front of a public official and also made before an official authorized to make the deed. The authority to make this authentic deed is the request of the parties and for the validity of an agreement 4 conditions are needed, namely: ${ }^{9}$

a) Agreement of the parties

b) The ability to make an engagement

c) Object/specific thing

d) A cause that is lawful.

So for an agreement to be said to be a valid agreement, it must meet the requirements as listed above.

\footnotetext{
${ }^{6}$ Soekanto, Soejono. (1986). Pengantar Penelitian Hukum, Jakarta : UI Press. p. 6.

${ }^{7}$ Ibid.

${ }^{8}$ Subekti, (2001). Pokok-pokok Hukum Perdata. Jakarta :Intermasa. p. 36.

${ }^{9}$ Article 1320 Civil Code
} 
In principle, the deed made by the notary is an agreement of the parties where the notary only worries the wishes of the parties. What the parties want is then stated in the deed, which of course is all in accordance with the wishes of the parties that have been agreed upon together. So that if one of the parties then feels that someone is disadvantaged, in this case it is the responsibility of the parties, not the responsibility of the notary. In fact, deeds made by notaries are evidence that the parties can use. Unless there are changes made by a notary without the knowledge of one of the parties against the law. ${ }^{10}$

In essence, notarial deeds are authentic deeds that legally have perfect evidentiary value so that without presenting the parties or notaries who made them, the deed can be categorized as perfect and true evidence. However, if the notary who made it is required to ask for information, then there is a legal mechanism that must be passed first, namely the Notary Honor Council (mkn) which has been legally regulated in Article 66 of the UUJN which must obtain approval from the Notary Honorary Council (mkn) because it involves Confidentiality of the contents of the deed which must be disclosed by a notary in providing information. This means that the notary is still obliged to provide information if it is needed and the rules that are violated in providing such information cannot. ${ }^{11}$

Liability on a civil basis for the authentic deed he makes, the notary is only responsible for the formal validity of an authentic deed and not for the material of the authentic deed. The legal basis used in the civil liability for a deed made by a notary is if the notary makes a mistake because of broken promises as determined in the provisions of Article 1234 of the Civil Code and acts against the law as stipulated in the provisions of Article 1365 of the Civil Code, it is explained "every act against or violates law which results in loss of loss to others, obliges the person who due to his fault has published the loss or compensated for the loss ". Notaries who receive civil sanctions should be prepared to face the lawsuit of the aggrieved party, which is a lawsuit due to an illegal act. If investigated further, the act fulfills the elements against the law as regulated in Article 1365 of the Civil Code. The article reads: "Every act that violates the law and brings harm to others, obliges the person who caused the loss because of his mistake to compensate for the loss". ${ }^{12}$

\subsection{Obstacles and Solutions in the Implementation of Notary Responsibilities for the} Authentic Deed Made in Kendari City

3.2.1 Barriers to Execution of Notary Public Responsibilities for the Authentic Deed He Has Made

The obstacle in implementing the notary's responsibility towards the authentic deed he makes is regarding the good faith of the parties, this is very much needed in the process of making a notary deed, especially in presenting formal data by the parties

10 Results of Interview with Albert Widya Arung Raya, SH, M.Kn. Notary in Kendari City, February 10, 2020, at 15:15 WIT.

11 Ibid.

12 Results of Interview with Agus Jaya, SH. Notary in Kendari City, February 03 2020, at 13.10 WITA. 
and conveying the will by the parties. ${ }^{13}$ so that we must always prioritize the principle of prudence because in the information provided by the parties facing it, it may not be in accordance with the truth, which could harm all parties including the notary itself. ${ }^{14}$ So that if one of the parties then feels that someone is disadvantaged, in this case it is the responsibility of the parties, not the responsibility of the notary. In fact, deeds made by notaries are evidence that the parties can use. Unless there are changes made by a notary without the knowledge of one of the parties against the law. Then the party who is injured can of course sue for civil harm to the notary, but this of course must be proven first or there are legal provisions that are violated or the fulfillment of legal provisions in the authentic deed made by the notary ${ }^{15}$.

\subsubsection{Solutions in the Implementation of Notary Responsibilities for the Authentic} Deed He Made

The solution in the implementation of the notary's civil responsibility towards the authentic deed he makes is that the application of the precautionary principle must run in accordance with the notary's precautionary principle, if there is a good relationship, mutual understanding between the Notary and the parties, violations of the law can be avoided. In the notary's principle of prudence in carrying out his position, it is necessary to be careful from the notary himself in accepting a job or client. When the notary is in doubt about the information provided by the parties, as a notary the right and the obligation to dig up more information because the notary only gets formal evidence. ${ }^{16}$ As well as following the coordination that has been stipulated in the laws and regulations, especially in article 1320 Kuhperdata and always upholds the principles of prudence and recognition of clients. ${ }^{17}$

If it is proven that there is a violation committed by the notary concerned and it is detrimental to one of the parties because of the deed he made. Regarding the civil claim, the notary concerned is obliged to compensate for the civil loss if proven. ${ }^{18} \mathrm{Of}$ course talking about compensation must first be proven legally the losses that arise, so that if there is such a thing, of course the advice that can be given is to remain responsible for the losses that arise. The question of how much the incurred loss is, of course, the domain of the court regarding its execution and how many responsibilities must be fulfilled, only communication with the parties concerned. ${ }^{19}$

13 Results of Interview with Muh. Farid Azhari Tahrir, SH, M.Kn .. Notary in Kendari City, January 20, 2020, at 15.00 WITA

14 Results of Interview with Agus Jaya, SH. Notary in Kendari City, February 03 2020, at 13.10 WITA.

15 Results of Interview with Albert Widya Arung Raya, SH, M.Kn. Notary in Kendari City, February 10, 2020, at 15:15 WIT.

16 Results of Interview with Agus Jaya, SH. Notary in Kendari City, February 03 2020, at 13.10 WITA.

17 Results of Interview with Muh. Farid Azhari Tahrir, SH, M.Kn .. Notary in Kendari City, January 20, 2020, at 15.00 WITA

18 Results of Interview with Albert Widya Arung Raya, SH, M.Kn. Notary in Kendari City, February 10, 2020, at 15:15 WIT.

19 Ibid. 


\section{Closing}

Based on the results of the research that has been done, the authors can draw conclusions, that:

1. Implementation of Civil Notary Responsibilities for Authentic Deed Made, the notary is only responsible for the formal correctness of an authentic deed and not for the authentic deed material. The legal basis used in the civil liability for a deed made by a notary is if the notary makes a mistake because of broken promises as determined in the provisions of Article 1234 of the Civil Code and acts against the law as stipulated in the provisions of Article 1365 of the Civil Code, it is explained "every act against or violates law which results in loss of loss to others, obliges the person who due to his fault has published the loss or compensated for the loss ".

2. Barriers and Solutions in the Implementation of Notary Responsibilities for the Authentic Deed that he makes, namely:

a. Barriers to Execution of Notary Public Responsibilities for the Authentic Deed He Has Made. If one of the parties then feels that someone is disadvantaged, in this case it is the responsibility of the parties, not the responsibility of the notary public. In fact, deeds made by notaries are evidence that the parties can use. Unless there are changes made by a notary without the knowledge of one of the parties against the law.

b. Solutions in the Implementation of Notary Responsibilities for the Authentic Deed He Made. If it is proven that there is a violation committed by the notary concerned and it is detrimental to one of the parties because of the deed he made. Regarding the civil claim, the notary concerned is obliged to compensate for the civil loss if proven. Of course talking about compensation must first be proven legally the losses that arise, so that if there is such a thing, of course the advice that can be given is to remain responsible for the losses that arise. The question of how much the incurred loss is, of course, the domain of the court regarding its execution and how many responsibilities must be fulfilled, only communication with the parties concerned.

\section{References}

Books:

[1] Anshori, Abdul Ghofur. (2009). Lembaga Kenotariatan Indonesia. Yogyakarta: UII Press

[2] Subekti, (2001). Pokok-pokok Hukum Perdata. Jakarta: Intermasa.

[3] Soekanto, Soejono. (1986). Pengantar Penelitian Hukum, Jakarta: UI Press

[4] Ngadino, (2019). Tugas Dan Tanggung Jawab Jabatan Notaris di Indonesia. Semarang: UPT Penerbitan Universitas PGRI Semarang Press. 
[5] Tedjosaputro, Liliana. (1991). Malpraktek Notaris Dan Hukum Pidana. Semarang: Agung.

Internet:

https://id.wikipedia.org/wiki/Notaris (Accessed on October 2, 2019 at 01.08 WITA).

Regulation:

Article 1320 Civil Code

Interview:

[1] Results of Interview with Agus Jaya, SH. Notary in Kendari City, February 03 2020, at 13.10 WITA.

[2] Results of Interview with Albert Widya Arung Raya, SH, M.Kn. Notary in Kendari City, February 10, 2020, at 15:15 WIT.

[3] Results of Interview with Muh. Farid Azhari Tahrir, SH, M.Kn .. Notary in Kendari City, January 20, 2020, at 15.00 WITA 